УДК 620.92

\title{
ПЕРСПЕКТИВИ РОЗВИТКУ БІОЕНЕРГЕТИКИ ЯК ІНСТРУМЕНТУ ЗАМІЩЕННЯ ПРИРОДНОГО ГАЗУ В УКРАЇНІ
}

\author{
Гелетуха Г.Г., канд. тех. наук, Желєзна Т.А., канд. тех. наук, Гайдай О.I. \\ Інститут технічної теплофізики НАН Украӥни, вул. Желябова, 2а, Київ, 03680, Україна
}

Розглянуто поточний стан та перспективи розвитку біоенергетики в Україні до 2020 року. Проаналізовано механізми стимулювання розвитку даного сектору у відповідності до урядових документів, прийнятих у 2014 році.
Рассмотрено современное состояние и перспективы развития биоэнергетики в Украине до 2020 года. Проанализированы механизмы стимулирования развития данного сектора в соответствии с правительственными документами, принятыми в 2014 году.
The paper covers the present state and prospects for the development of bioenergy in Ukraine until 2020. Some supporting instruments for the bioenergy sector introduced by the government in 2014 are analyzed.

Бібл. 10, табл. 5, рис. 3 .

Ключові слова: біомаса, біопаливо, біогаз, біоенергетика, потенціал біомаси, біоенергетичне обладнання.

АЕС - атомна електростанція;

АПК - агропромисловий комплекс;

ВДЕ - відновлювані джерела енергії

ВКЕ - валове кінцеве енергоспоживання;

ЖКГ - житлово-комунальне господарство;

ЗППЕ - загальне постачання первинної енергії;

НКРЕКП - Національна комісія, що здійснює державне регулювання у сферах енергетики та комунальних послуг;

ПГ - природний газ;

\section{Стан розвитку біоенергетики в світі}

Відновлювані джерела енергії наразі відіграють помітну роль у світовій енергетиці. За даними 2011 р. їх внесок до валового кінцевого енергоспоживання становить більше $18 \%$, в тому числі біомаса - 14 \% ВКЕ або 76 \% загального внеску всіх ВДЕ (рис. 1) [1]. В Свропейському Союзі ситуація схожа: частка відновлюваних джерел у валовому кінцевому енергоспоживанні складає $15 \%$ (2013 р.), в тому числі біомаса близько 9 \% ВКЕ або 62 \% загального внеску всіх ВДЕ. В окремих країнах СС частка біомаси від усіх відновлюваних джерел коливається від 30...40 \% (Люксембург, Кіпр, Ірландія) до $80 \ldots 95 \%$ (Естонія, Латвія, Литва, Угорщина,
ТЕЦ - теплоелектроцентраль;

ТЕС - теплова електростанція;

ТПВ - тверді побутові відходи;

ЦТ - централізоване теплопостачання;

н.е. - нафтовий еквівалент;

у.П. - умовне паливо.

\section{Нижні індекси:}

т - тепловий;

e - електричний.

Польща, Фінляндія) (рис. 2) [2]. До 2020 р. внесок ВДЕ до валового кінцевого енергоспоживання ЄС має досягти 20 \% (обов'язкова ціль), а до 2030 р. може сягнути щонайменше $27 \%$ (нова обов'язкова ціль, поставлена Свропейською Радою у жовтні 2014 р.).

\section{Стан розвитку біоенергетики в Україні та можливості по заміщенню природного газу до 2020 року}

Порівняємо наведені дані із ситуацією в Україні. Згідно даних енергетичного балансу України за 2013 р., який був підготовлений Державною службою статистики України [3], частка відновлюваних джерел енергії у вало- 
вому кінцевому енергоспоживанні становить $3,62 \%$, в тому числі біомаса - 2,28 \%, що складає $63 \%$ від усіх ВДЕ або 1,61 млн. т н.е. (табл. 1). У порівнянні з 2012 р. спостерігається помітне зростання внеску біомаси до загального постачанні первинної енергії - на 23 \%, 3 1,52 до 1,88 млн. т н.е./рік (рис. 3). На 2014 р. ми прогнозуємо ще більший ріст у зв'язку 3 нагальною необхідністю заміщення природного газу альтернативними видами палива та впровадженням заходів, що сприяють цьому процесу.

Національним планом дій 3 відновлюваної енергетики встановлено загальну мету з роз-витку цього сектору в Україні до 2020 р. - внесок ВДЕ до валового кінцевого енергоспоживання має досягти $11 \%$ у 2020 р. у відповідності до зобов' язань України як члена Енергетичного спів-товариства [4]. Біомаса є вагомою складовою відновлюваних джерел енергії, й, згідно Націона-льного плану дій, основний внесок біомаси передбачений в секторі опалення/охолодження - 5000 тис. т н.е./ рік у 2020 р., що становитиме 85\% внеску всіх ВДЕ (табл. 2). Крім того, до 2020 р. заплановано встановлення 950 МВте енергообладнання на біомасі та використання 390 тис. т н.е./рік біопалив (біоетанолу та біодизелю) на транспорті.

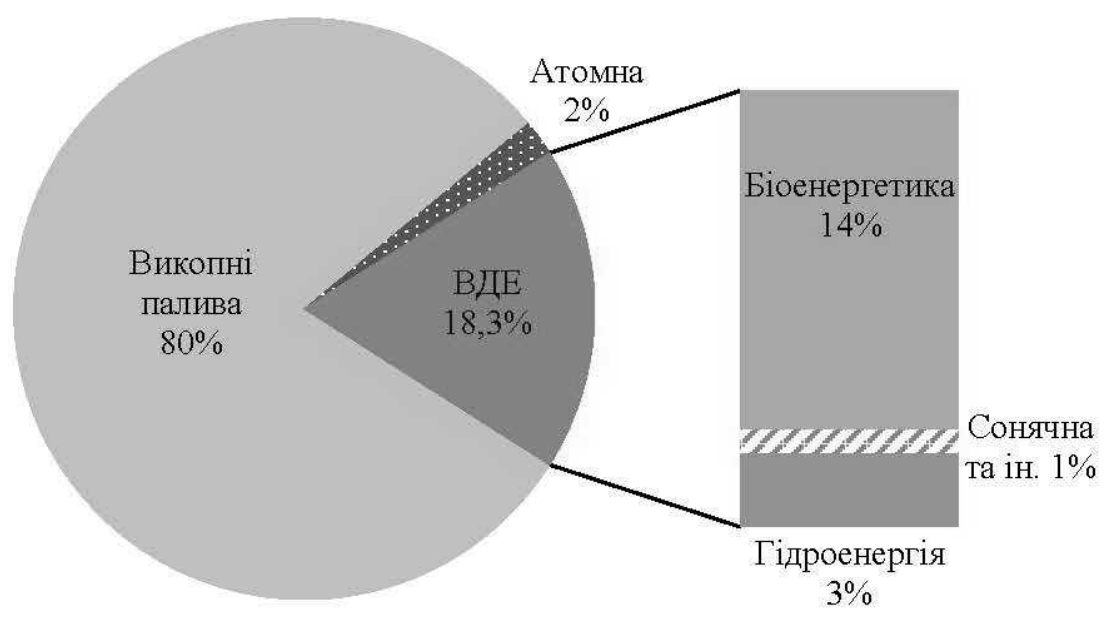

Рис. 1. Структура валового кінцевого енергоспоживання у світі (загалом 339000 ПДок), 2011 р. [1].

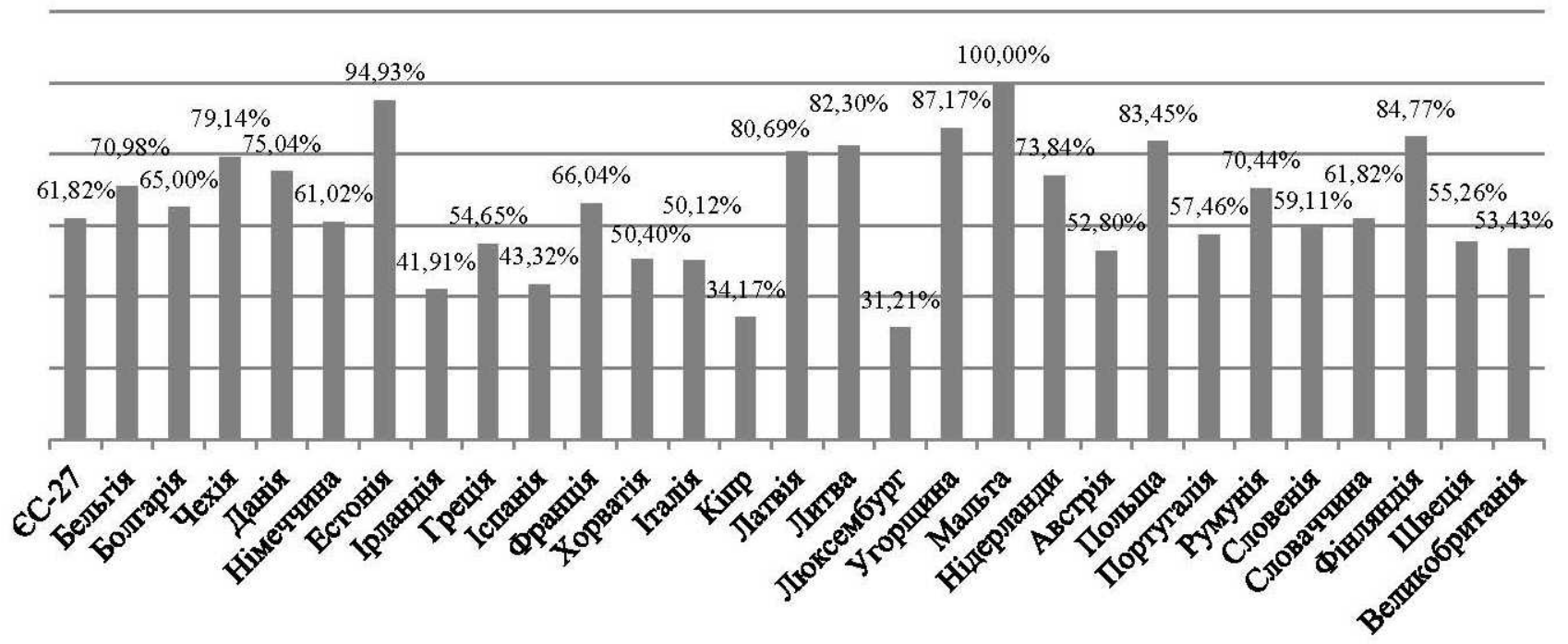

Рис. 2. Частка біомаси від усіх ВДЕ у кінцевому енергоспоживанні СС, 2011 р. [2]. 
Табл. 1. Місце відновлюваних джерел енергії та біомаси в енергетичному балансі України

\begin{tabular}{|l|c|c|c|c|}
\hline \multicolumn{1}{|c|}{ Показники } & 2010 & 2011 & 2012 & 2013 \\
\hline Частка відновлюваних джерел в ЗППЕ & $2,00 \%$ & $1,99 \%$ & $2,02 \%$ & $2,73 \%$ \\
\hline Частка відновлюваних джерел у ВКЕ* & $2,98 \%$ & $2,80 \%$ & $2,95 \%$ & $3,62 \%$ \\
\hline Біопалива/відходи у ЗППЕ, млн. т н.е. & $1,48(1,12 \%)$ & $1,56(1,23 \%)$ & $1,52(1,23 \%)$ & $1,88(1,62 \%)$ \\
\hline Біопалива/відходи у ВКЕ*, млн. т н.е. & $1,40(1,86 \%)$ & $1,45(1,88 \%)$ & $1,47(1,99 \%)$ & $1,61(2,28 \%)$ \\
\hline Частка біопалив/відходів від усіх ВДЕ у ВКЕ* & $62 \%$ & $67 \%$ & $68 \%$ & $63 \%$ \\
\hline
\end{tabular}

*Розрахунок авторів за даними офіційного енергетичного балансу України за 2010-2013 pp.

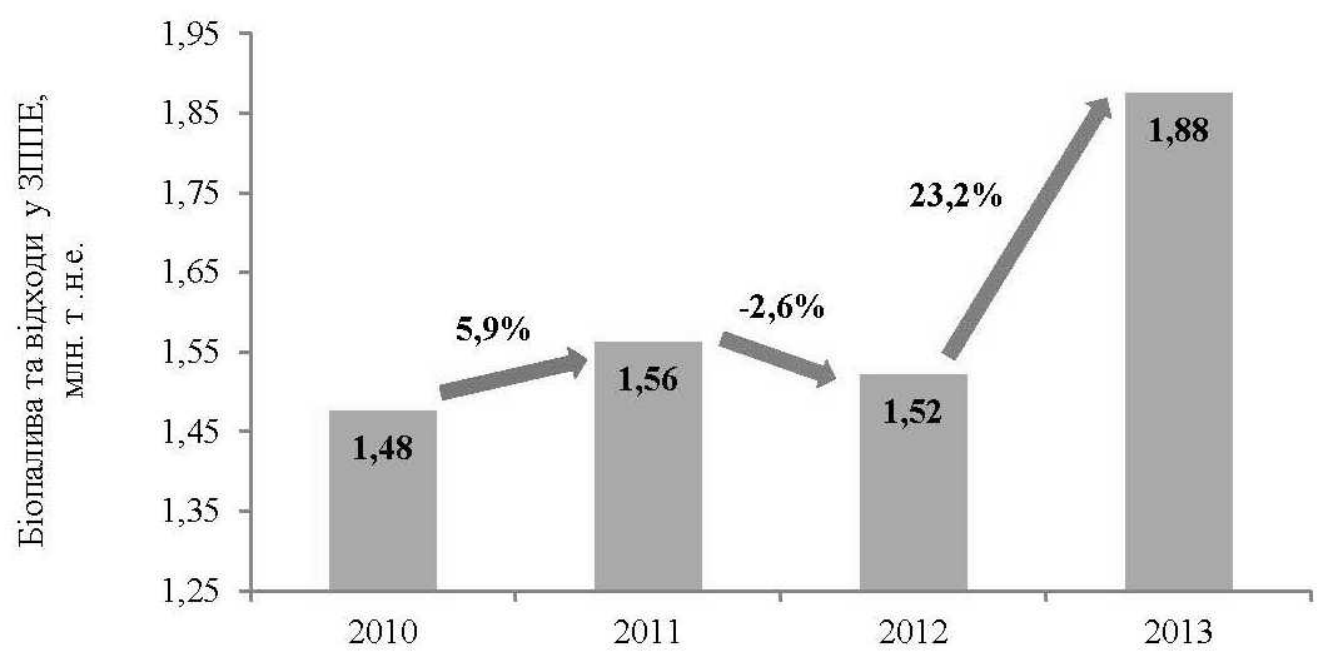

Рис. 3. Внесок біомаси та відходів до загального постачання первинної енергії в Україні, млн. т н.е.

Табл. 2. Національна індикативна ціль відновлюваних джерел енергії у валовому кінцевому енергоспоживанні до 2020 р. та розрахункові траєкторії їі досягнення [4]

\begin{tabular}{|r|c|c|c|c|c|c|c|c|}
\hline Показники & 2009 & 2014 & 2015 & 2016 & 2017 & 2018 & 2019 & 2020 \\
\hline ВДЕ: виробництво теплової енергії, \%, & 3,4 & 5,7 & 6,7 & 7,7 & 8,9 & 10,0 & 11,2 & 12,4 \\
- у т.ч. біомаса, тис. т н.е. & 1433 & 2280 & 2700 & 3100 & 3580 & 4050 & 4525 & $5000(85 \% *)$ \\
\hline ВДЕ: виробництво електроенергії, \%, & 7,1 & 7,6 & 8,3 & 8,8 & 9,7 & 10,4 & 10,9 & 11,0 \\
- у т.ч. біомаса, МВте & 0 & 40 & 250 & 380 & 520 & 650 & 780 & 950 \\
тверда біомаса & & 28 & 175 & 260 & 360 & 455 & 540 & $660(12 \%)$ \\
біогаз & & 12 & 75 & 120 & 160 & 195 & 240 & $290(5 \%)$ \\
\hline ВДЕ: транспорт, \%, & 1,5 & 4,1 & 5,0 & 6,5 & 7,5 & 8,2 & 9,0 & 10,0 \\
- у т.ч. біоетанол, біодизель, тис. т н.е. & 0 & 110 & 150 & 220 & 265 & 300 & 340 & $390(77 \%)$ \\
\hline Загальна частка ВДЕ у ВКЕ, \% & 3,8 & 5,9 & 6,7 & 7,4 & 8,3 & 9,1 & 10,1 & 11,0 \\
\hline
\end{tabular}

* Частка біомаси від внеску всіх ВДЕ в даному секторі (розрахунок авторів).

Зазначені цифри по внеску біомаси до виробництва енергії у 2020 р. відповідають заміщенню природного газу в обсязі 6,25 млрд. м $^{3} /$ рік у секторі теплової енергії та 0,95 млрд. м³/рік у секторі електроенергії (прогнозуючи, що 90 \% електричних потужностей на твердій біомасі буде працювати в режимі ТЕЦ). Віднімаючи від загального запланованого обсягу заміщення 
природного газу (7,2 млрд. м³рік) об'єм скорочення, що вже досягнутий на сьогодні за рахунок біомаси (1,93 млрд. м³/рік), отримуємо об'єм газу $(5,27$ млрд. м³/рік), який має бути додатково заміщений біомасою до 2020 р. згідно Національного плану дій з відновлюваної енергетики.

Для виконання поставленої цілі в Україні $є$ достатній потенціал біомаси, доступної для виробництва енергії - більше 27 млн. т у.п./рік за оцінками 2013 р. [5]. Основними складовими потенціалу є первинні відходи сільського господарства (солома, відходи виробництва кукурудзи на зерно і соняшника) та енергетичні культури, вирощування яких у промислових масштабах активно розвивається в країні останніми роками. Загалом економічний потенціал відходів сільського господарства складає 12,2 млн. т у.п./рік, енергетичних культур - 10 млн. т у.П./рік.

Наразі на енергетичні потреби в Україні використовується лише близько $10 \%$ загально- го потенціалу біомаси - 2,7 млн. т у.п./рік (табл. 3). Головним чином це деревна біомаса у вигляді дров, тріски, гранул/брикетів (загалом 86 \% всього річного обсягу використання біомаси) та лушпиння соняшника (8 \%). Найменш активно застосовуються рослин ні відходи - 94 тис. т соломи на рік, що становить $<1 \%$ економічного потенціалу соломи в Україні.

На сьогодні в Україні працюють більше 4 тис. сучасних котлів на деревині, більше 100 котлів на соломі й близько 70 котлів на лушпинні соняшника. С кілька ТЕЦ на твердій біомасі: 1 - на деревині в системі централізованого теплопостачання, 3 - на лушпинні соняшника на підприємствах масложирової галузі. Крім того, населення використовує кілька десятків тисяч пічок та побутових котлів на дровах та деревних гранулах. Загальна встановлена потужність зазначеного біоенергетичного обладнання становить більше $3650 \mathrm{MBT}_{\text {т }}$ та $14 \mathrm{MBT}_{\mathrm{e}}$ (табл. 4).

Табл. 3. Використання біомаси для виробництва енергії в Україні (2013 р.)

\begin{tabular}{|c|c|c|c|c|}
\hline \multirow[t]{2}{*}{ Вид біомаси / біопалива } & \multicolumn{2}{|c|}{$\begin{array}{l}\text { Річний обсяг } \\
\text { споживання* }\end{array}$} & \multirow{2}{*}{$\begin{array}{l}\text { Частка в річ- } \\
\text { ному обсязі } \\
\text { споживання }\end{array}$} & \multirow{2}{*}{$\begin{array}{c}\text { Частка вико- } \\
\text { ристання } \\
\text { економічно- } \\
\text { го потенціа-лу }\end{array}$} \\
\hline & $\begin{array}{l}\text { натуральні } \\
\text { одиниці }\end{array}$ & $\begin{array}{l}\text { тис. т } \\
\text { у.П }\end{array}$ & & \\
\hline Солома зернових культур та ріпаку & 94 тис. т & 48 & $1,8 \%$ & $0,9 \%$ \\
\hline Дрова (населення) & 5,0 млн. м $^{3}$ & 1200 & $45,1 \%$ & \multirow[b]{2}{*}{$>90 \%$} \\
\hline $\begin{array}{l}\text { Деревна біомаса (крім споживання } \\
\text { населенням) }\end{array}$ & 3,2 млн. т & 1089 & $40,9 \%$ & \\
\hline Лушпиння соняшнику & 380 тис. т & 208 & $7,8 \%$ & $41 \%$ \\
\hline Біоетанол & 65 тис. $\mathrm{T}$ & 60 & $2,3 \%$ & $6,1 \%$ \\
\hline Біодизель & 18 тис. $\mathrm{T}$ & 23 & $0,9 \%$ & $4,8 \%$ \\
\hline Біогаз з відходів сільського господарства & 22,3 млн. м $^{3}$ & 14 & $0,5 \%$ & $4,4 \%$ \\
\hline Біогаз з полігонів ТБО & 31,2 млн. м ${ }^{3}$ & 21 & $0,8 \%$ & $8,1 \%$ \\
\hline Всього & & $2662 * *$ & $100 \%$ & \\
\hline
\end{tabular}

Для додаткового заміщення 5,27 млрд. м $^{3} /$ рік природного газу біомасою до 2020 р. необхідно впровадження $12485 \mathrm{MBT}_{\mathrm{T}}+756 \mathrm{MBT}_{\mathrm{e}}$ в побутовому секторі, житлово-комунальному господарстві, бюджетній сфері, у промислових та комерційних споживачів (таблиця 5). Найбільший ріст використання біомаси й, відповідно, заміщення газу, прогнозується в ЖКГ та бюджетній сфері - на 3,2 млрд. м $^{3} /$ рік до 2020 р. Для забезпечення необхідним обсягом палива всіх запланованих 
до впровадження біоенергетичних установок потрібне широке залучення відходів сільського господарства (соломи, стебел кукурудзи й соняшника) та енергетичних культур до паливно-енергетичного балансу країни.

Крім того, необхідною умовою $\epsilon$ збільшення обсягів рубок - від поточних 55...60 \% річного приросту деревини в Україні до $85 . .90 \%$ річного приросту, як це практикується наразі в країнах Євросоюзу.

Табл. 4. Виробництво енергії з біомаси в Україні, 2013 р.

\begin{tabular}{|c|c|c|c|c|c|}
\hline Сектор / Тип обладнання & $\begin{array}{l}\text { Кількість, } \\
\text { од. }\end{array}$ & $\begin{array}{c}\text { Встановлена } \\
\text { потужність, } \\
\mathrm{MBT}_{\mathrm{\tau}}\left(+\mathrm{MBT}_{\mathrm{e}}\right)\end{array}$ & $\begin{array}{l}\text { Заміщення } \\
\text { ПГ, млрд. } \\
\text { м³/рік }\end{array}$ & $\begin{array}{l}\text { Виробництво } \\
\text { теплоти, } \\
\text { тис. Гкал/рік }\end{array}$ & $\begin{array}{c}\text { Зниження } \\
\text { виквдів } \mathrm{CO}_{2} \\
\text { млн. т/рік } \\
\end{array}$ \\
\hline \multicolumn{6}{|l|}{ Населення: } \\
\hline Традиційні пічки на дровах & 50000 & 500 & 0,20 & 1718 & 0,40 \\
\hline $\begin{array}{l}\text { Побутові котли на дровах та } \\
\text { деревних гранулах } 10 \ldots 50 \text { кВт }\end{array}$ & 50000 & 1500 & 0,61 & 5155 & 1,19 \\
\hline Всього, населення & 100000 & 2000 & 0,81 & 6873 & 1,59 \\
\hline \multicolumn{6}{|l|}{ ЖКГ та бюджетна сфера: } \\
\hline Котли на деревині $0,5 \ldots 10 \mathrm{MBT}_{\tau}$ & 690 & 345 & 0,14 & 1186 & 0,27 \\
\hline ТЕЦ на деревині & 1 & $10(+6)$ & 0,004 & 69 & 0,01 \\
\hline Всього, ЖКГ та бюджетна сфера & 691 & $355(+6)$ & 0,144 & 1255 & 0,28 \\
\hline \multicolumn{6}{|l|}{$\begin{array}{c}\text { Промислові } \\
\text { комериіиині споживачі: } \\
\end{array}$} \\
\hline Котли на деревині $0,1 \ldots 5 \mathrm{MBT}_{\tau}$ & 2000 & 1000 & 0,76 & 6874 & 1,50 \\
\hline Котли на соломі $0,1 \ldots 1 \mathrm{MBT}_{\tau}$ & 110 & 55 & 0,04 & 378 & 0,08 \\
\hline Котли на лушпинні соняшника & 65 & 195 & 0,15 & 1340 & 0,29 \\
\hline ТЕЦ на лушпинні соняшника & 3 & $64(+8)$ & 0,02 & 437 & 0,05 \\
\hline $\begin{array}{l}\text { Всього, промислові/ } \\
\text { комериійні спожсивачі }\end{array}$ & 2178 & $1314(+8)$ & 0,98 & 9029 & 1,92 \\
\hline ВСЬОГО & 102869 & $3669(+14)$ & 1,93 & 17157 & 3,79 \\
\hline
\end{tabular}

\section{Механізми стимулювання розвитку біоенергетики в Україні}

У 2014 р. в Україні було прийнято низку урядових постанов, спрямованих на стимулювання заміщення природного газу альтернативними паливами та видами енергії та на гармонізацію сектору ВДЕ України 3 європейським [4, 6-10]. Зокрема, Планом коротко- та середньострокових заходів щодо скорочення обсягу споживання природного газу на період до 2017 року [6] передбачено 19 важливих заходів, в тому числі:

- Надання статусу першочергових інвестиційним проектам 3 переведення споживачів з природного газу на інші види палива та енергії.
- Вдосконалення методики розрахунку тарифу на виробництво теплової енергії з інших видів палива, ніж природний газ: застосування механізму прискореної амортизації обладнання; встановлення граничного рівня регуляторної норми доходів для таких проектів не нижче 25 \%.

- Спрощення порядку передачі у концесію, оренду та зняття заборони на приватизацію об'єктів теплоенергетики комунальної форми власності.

- Імплементація терміну «біомаса» у національне законодавство відповідно до Директиви 2009/28/EC.

- Розробка технічних умов приймання в газотранспортну систему України біометану, механізму стимулювання його виробництва та 
споживання.

- Внесення змін до Енергетичної стратегї України до 2030 р. в частині скорочення споживання природного газу, збільшення обсягу використання відновлюваних джерел енергії та альтернативних видів палива.

- Спрощення процедури землевідведення під об'єкти виробництва теплової та/або електричної енергії 3 використанням інших видів палива, ніж природний газ.

- Скорочення строків видачі та кількості дозвільних документів для реалізації проектів по заміщенню газу.

- Внесення змін до Законів України «Про теплопостачання» та «Про природні монополії» стосовно переходу на альтернативні види палива та до стимулюючого регулювання відповідних суб'єктів господарювання.
Крім того, уведено додаткові механізми стимулювання заміщення природного газу у сфері теплопостачання населення (Постанова КМУ № 293 від 09.07.2014) [7] та бюджетних організацій (Постанова КМУ № 453 від 10.09.2014) [8]. Так, згідно Постанови КМУ № 293, у разі виробництва теплової енергії для населення різниця між тарифом на виробництво теплової енергії на теплогенеруючих установках (крім ТЕЦ, ТЕС і АЕС) з використанням будь-яких видів палива та енергії (за винятком природного газу) i тарифом на виробництво теплової енергії для потреб населення на вказаних установках 3 використанням будь-яких видів палива та енергії (за винятком природного газу) підлягає компенсації 3 державного бюджету. Розмір компенсації різниці в зазначених тарифах на виробництво теплової енергії

Табл. 5. Впровадження додаткового біоенергетичного обладнання для виробництва енергії в Україні до 2020 р. (у порівнянні з 2013 р.)

\begin{tabular}{|c|c|c|c|c|c|}
\hline Сектор / Тип обладнання & $\begin{array}{l}\text { Кількість, } \\
\text { од }\end{array}$ & $\begin{array}{l}\text { Встановлена } \\
\text { потужність, } \\
\mathrm{MBT}_{\mathrm{T}}\left(+\mathrm{MBT}_{\mathrm{e}}\right)\end{array}$ & $\begin{array}{l}\text { Заміщення } \\
\text { ПГ, млрд. } \\
\text { м²/рік }\end{array}$ & $\begin{array}{l}\text { Виробництво } \\
\text { теплоти, } \\
\text { тис. Гкал/рік }\end{array}$ & $\begin{array}{c}\text { Зниження } \\
\text { викидів } \mathrm{CO}_{2}, \\
\text { млн. т/рік }\end{array}$ \\
\hline \multicolumn{6}{|l|}{ Населення: } \\
\hline $\begin{array}{l}\text { Побутові котли на дровах та } \\
\text { деревних гранулах } 10 \ldots 50 \text { кВт }\end{array}$ & 30000 & 900 & 0,36 & 3093 & 0,71 \\
\hline $\begin{array}{l}\text { Перехід населення від індиві- } \\
\text { дуальних до систем помірно ЦТ: } \\
\text { Котли на соломі/стеблах } 1 . . .10 \text { МВт }\end{array}$ & 1300 & 2600 & 1,05 & 8936 & 2,06 \\
\hline Всього, населення & 31300 & 3500 & 1,41 & 12029 & 2,78 \\
\hline \multicolumn{6}{|l|}{ ЖКГ та бюджетна сфера: } \\
\hline Котли на деревині $0,5 \ldots 10$ MBт & 560 & 280 & 0,11 & 962 & 0,22 \\
\hline Котли на соломі/стеблах $1 . . .10 \mathrm{MBT}_{\text {т }}$ & 1500 & 3750 & 1,52 & 12888 & 2,97 \\
\hline ТЕЦ на деревині & 9 & $270(+54)$ & 0,11 & 1856 & 0,21 \\
\hline ТЕЦ на соломі/стеблах & 50 & $1770(+300)$ & 0,72 & 12166 & 1,40 \\
\hline ТЕЦ на біомасі енергокультур & 50 & $1770(+300)$ & 0,72 & 12166 & 1,40 \\
\hline Всього, ЖКГ та бюджетна сфера & 2169 & $7840(+654)$ & 3,18 & 40038 & 6,22 \\
\hline \multicolumn{6}{|l|}{ Промислові / комериійні споживачі: } \\
\hline Котли на соломі/стеблах $0,1 \ldots 1$ МВт & 1190 & 595 & 0,45 & 4090 & 0,89 \\
\hline Котли на лушпинні соняшника & 5 & 40 & 0,03 & 275 & 0,06 \\
\hline ТЕЦ на деревині & 10 & $300(+60)$ & 0,11 & 2062 & 0,22 \\
\hline ТЕЦ на лушпинні соняшника & 7 & $210(+42)$ & 0,08 & 1443 & 0,16 \\
\hline $\begin{array}{l}\text { Всього, промислові / } \\
\text { комериіийні спожсивачі }\end{array}$ & 1212 & $1145(+102)$ & 0,68 & 7870 & 1,33 \\
\hline ВСЬОГО & 34681 & $12485(+756)$ & 5,27 & 59937 & 10,33 \\
\hline
\end{tabular}


не може бути вищим, ніж різниця між фактично встановленим тарифом на теплову енергію для населення та ii собівартістю 3 урахуванням граничного рівня рентабельності не вище $21 \%$. Треба зазначити, що на практиці, нажаль, цей механізм не працює через його недосконалість. Основною проблемою $є$ те, що в Постанові мова іде про тариф на виробництво теплової енергії, тоді як більшість теплокомуненерго України мають затверджений «сумарний» тариф, тобто на виробництво, транспортування й постачання, без окремого виділення тарифу на виробництво. Наразі ведеться робота 3 підготовки нової редакції Постанови № 293, в якій буде виправлено цей та інші недоліки.

Постановою КМУ № 453 Національній комісії, що здійснює державне регулювання у сферах енергетики та комунальних послуг, та органам місцевого самоврядування рекоменду-ється встановлювати тариф на виробництво теплової енергії для бюджетних установ та організацій на теплогенеруючих установках (крім ТЕЦ, ТЕС і АЕС) 3 використанням будь-яких видів палива та енергії (за винятком природного газу) на рівні діючого тарифу на виробництво теплової енергії для бюджетних установ та організацій з використанням природного газу та здійснювати його перегляд у разі зміни граничного рівня ціни на природний газ, що використовується для виробництва теплової енергії для бюджетних установ та організацій. Наразі також готується нова, більш вдосконалена редакція цієї Постанови.

Механізм стимулювання населення до впровадження енергоефективних заходів уведено Постановою КМУ № 491 від 1.10.2014 [9]. Цей механізм полягає у відшкодуванні частини тіла кредиту, залученого на придбання котлів з використанням будь-яких видів палива та енергії (за винятком природного газу). Відшкодування частини суми кредиту проводиться одноразово кожному позичальнику - фізичній особі в розмірі $20 \%$ суми кредиту, залученого ним за одним кредитним договором в уповноваженому банку на придбання котла, але не більш як 5000 гривень за кожним кредитним договором. За даними Держенергоефективності України, станом на 17.12.2014 вже видано кредитів на суму більше 19 млн. грн., кредит отримали 1155 домогосподарств.

План заходів 3 імплементації Директиви Європейського Парламенту та Ради 2009/28/ЄС [10] спрямований на гармонізацію українського та європейського законодавства в сфері відновлюваних джерел енергії. Серед іншого, План приділяе значну увагу питанням сталого розвитку. Передбачено розробку критеріїв сталості для рідкого та газоподібного палива, що виробляється з біомаси та використовується на транспорті, а також для рідкого палива, що виробляється 3 біомаси та призначається для енергетичного використання, іншого ніж транспорт. Також планується розробити технічні вимоги до виробництва і використання біопалив та біорідин із скороченням обсягів викидів парникових газів, починаючи 3 01.01.2017 не менш як на $50 \%$, а 3 01.01.2018 не менш як на 60 \% для біопалив та біорідин, вироблених на установках, введених в експлуатацію після 01.01.2017.

Додатковими факторами, що сприяли розширенню використання біопалив й скороченню споживання природного газу у 2014 р., були ріст цін на газ для населення та підприємств ЖКГ й встановлення адміністративних лімітів на споживання газу - 30 \% скорочення споживання для промисловості, бюджетної сфери та ЖКГ, 10 $\%$ - для населення.

Незважаючи на певний прогрес у розвитку біоенергетичних технологій протягом минулого року, дотепер залишається ряд бар'єрів та неврегульованих питань, що потребують якнайшвидшого вирішення. Основні проблеми такі:

- Виробникам теплової енергії з альтернативних палив (в тому числі біомаси) необхідно забезпечити безперешкодний доступ до теплових мереж. Місцеві теплокомуненерго зараз не зацікавлені в підключенні об'єктів альтернативної теплогенерації і чинять перешкоди у видачі технічних умов на підключення. Необхідні зміни до Закону України «Про теплопостачання», які б давали пріоритетний доступ об'єктам альтернативної теплогенерації до теплових мереж. 
- Необхідне спрощення процедури ліцензування. Згідно існуючого порядку, всі теплогенеруючі потужності на ВДЕ отримують ліцензію на виробництво теплової енергії i тариф в НКРЕКП. При цьому для котелень на викопних паливах є градація: при обсязі виробництва до 20 тис. Гкал/рік ліцензію і тариф видають органи місцевого самоврядування, при більшому обсязі - НКРЕКП. Вважаємо за необхідне впровадити подібну градацію й для виробників теплової енергії з ВДЕ.

- Недоліки Постанов КМУ № 293 та 453 заважають їх практичній реалізації. Наразі в НКРЕКП, Мінрегіонбуді та Держенергоефективності вже узгоджені необхідні зміни в ці постанови. Потрібно ï затвердження Кабінетом міністрів України.

- Більшість енергетичних культур досі не віднесені до розряду сільськогосподарських i ïx вирощування на землях сільськогосподарського призначення неможливе. Існуюча процедура включення до реєстру сільгоспкультур є довгою (передбачаються польові випробуванні протягом понад 3 років). Необхідне спрощення процедури внесення до реєстру для енергетичних культур.

- Держлісгоспи не мають достатньої техніки i мотивації для значного збільшення заготівлі деревного палива. Разом 3 тим існує ціла низка обмежень для приватних компаній по цьому виду діяльності. Потрібно врегулювати питання заготівлі деревного палива приватними компаніями, що мають відповідну техніку, в лісах державної форми власності.

- Існує недосконалість законодавства щодо «зеленого» тарифу на електроенергію, вироблену 3 біомаси та біогазу (некоректне визначення терміну «біомаса», нереальні вимоги щодо «місцевої складової» відповідних проектів, занижені з самого початку коефіцієнти «зеленого» тарифу на електроенергію 3 біомаси та біогазу). Наразі підготовлено кілька законопроектів, які вирішують більшість проблемних питань. Можна сподіватися, що необхідні зміни будуть внесені вже у першому кварталі 2015 р., оскільки вдосконалення законодавства щодо «зеленого» тарифу зазначено як один 3 пріоритетів в Коаліційній угоді.
Крім того, несприятливими для інвестування у біоенергетику були такі урядові рішення, прийняті у 2014 році: скасування звільнення від податку на прибуток для виробників електроенергіï 3 ВДЕ; скасування звільнення від податку на додану вартість операцій 3 продажу біопалив, в тому числі дров, тріски, гранул, брикетів; відмова від перегляду величини «зелених» тарифів на електроенергію 3 ВДЕ в залежності від курсу євро (НКРЕКП не перераховує ці тарифи 3 серпня 2014 р.); уведення акцизів на виробництво рідких біопалив.

\section{Висновки}

Сектор біоенергетики вже сьогодні фактично заміщує 1,93 млрд. $\mathrm{M}^{3} /$ рік природного газу в Україні. Експлуатується майже 3670 МВт теплової потужності на біомасі, в тому числі 2000 МВт у населення, 355 МВТ в ЖКГ і бюджетній сфері, більше 1300 МВт в промисловості. Прийнятий Урядом Національний план дій з ВДЕ до 2020 р ставить задачу перед сектором біоенергетики додатково замістити 5,27 млрд. ${ }^{3} /$ рік природного газу твердим біопаливом й досягти загального заміщення газу в обсязі 7,2 млрд. м $^{3} /$ рік у 2020 р. Це потребуватиме значного нарощування використання теплогенеруючого обладнання на біомасі: з 3670 МВт у 2013 р. до 16150 МВт у 2020 р. й відповідатиме фактичному збільшенню потужностей у 4,4 рази.

Виконання поставлених цілей неможливе без швидкого нарощування енергетичного споживання аграрних відходів й біопалива 3 енергетичних плантацій. Потужність котлів, що працюватимуть на відходах сільського господарства й енергетичних культурах збільшуватиметься 3310 МВт (8,5 \% загальної встановленої потужності на біомасі) у 2013 р. до $11050 \mathrm{MBT}$ (68 \%) в 2020. Фактично це еквівалентно росту споживання даних видів біомаси у 35 разів за найближчі 5 років.

У 2014 році Урядом прийнято ряд важливих постанов для стимулювання розвитку сектору біоенергетики. Необхідні подальші кроки в цьому ж напрямку, зокрема, зміни в Закон України “Про електроенергетику” щодо «зеленого» та- 
рифу, розвиток внутрішнього ринку біомаси як палива, стимулювання розширення виробництва котлів на біомасі.

\section{ЛІТЕРАТУРА}

1. Global Bioenergy Statistics. Publication of the World Bioenergy Association, 2014.

2. European Bioenergy Outlook. Statistical report, AEBIOM, 2013.

3. Енергетичний баланс України за 2013 рік. Експрес-випуск Державної служби статистики України від 28.11.2014 № 510/0/08.4вн-14.

4. Постанова КМУ № 902-р від 1.10.2104 «Про Національний план дій 3 відновлюваної енергетики на період до 2020 року».

5. Гелетуха Г.Г., Желєзна Т.А., Кучерук П.П., Олійник С.М., Трибой О.В. Біоенергетика в Україні: сучасний стан та перспективи розвитку. Частина 1 // Промислова теплотехніка. - 2015. T. 37, № 4. - С. 53-60.

6. Розпорядження КМУ № 1014-р від
16.10.2014 «Про затвердження плану коротко- та середньострокових заходів щодо скорочення обсягу споживання природного газу на період до 2017 року».

7. Постанова КМУ № 293 від 9.07.2014 «Про стимулювання заміщення природного газу у сфері теплопостачання».

8. Постанова КМУ № 453 від 10.09.2014 «Про стимулювання заміщення природного газу під час виробницт-ва теплової енергії для установ та організацій, що фінансуються з державного і місцевих бюджетів».

9. Постанова КМУ № 491 від 1.10.2014 «Про внесення змін до Порядку використання коштів, передбачених у держбюджеті для здійснення заходів щодо ефективного використання енергетичних ресурсів та енергозбереження».

10. Розпорядження КМУ № 791-р від 3.09.2014 «Про затвердження плану заходів 3 імплементації Директиви Європейського Парламенту та Ради 2009/28/ЄС». 
PROSPECTS FOR THE DEVELOPMENT OF BIOENERGY AS AN INSTRUMENT FOR NATURAL GAS REPLACEMENT IN UKRAINE

\section{Geletukha G.G., Zheliezna T.A., Haidai O.I.}

Institute of Engineering Thermophysics of the National Academy of Sciences of Ukraine, vul. Zhelyabova, 2a, Kyiv, 03680, Ukraine

The paper covers the present state and prospects for bioenergy development in Ukraine until 2020. Some supporting instruments introduced by the government in 2014 for the sector of renewable energy sources are analyzed. It is shown that according to the National Renewable Energy Action Plan the biggest contribution of biomass to energy production is expected in the heating and cooling sector. Some recent incentives for replacing natural gas in the heat supply of population and budgetfinanced institutions are analyzed, the advantages and disadvantages of the introduced instruments being discussed. It is shown that despite some obvious progress in the development of bioenergy in Ukraine further incentives are required for wider replacement of natural gas by renewable energy sources including biomass.

References 10, tables 5, figures 3 .

Key words: biomass, biofuel, biogas, bioenergy, potential of biomass, bioenergy equipment.
1. Global Bioenergy Statistics. Publication of the World Bioenergy Association, 2014.

2. European Bioenergy Outlook. Statistical report, AEBIOM, 2013.

3. Energy balance of Ukraine for 2013. Express release by the State Statistics Service of Ukraine N $510 / 0 / 08.4 \mathrm{BH}-14$ of 28.11 .2014 .

4. CMU Ordinance N 902-p of 01.10.2104 «On the National Renewable Energy Action Plan until 2020».

5. Geletukha G.G., Zheliezna T.A., Kucheruk P.P., Oliinyk Ye.M., Tryboi O.V. Bioenergy in Ukraine: state of the art and prospects for development. Part 1 // Promyshlennaya teplotekhnika. - 2015. -V. 37, №.4. - P. 53-60. (Rus)

6. CMU Ordinance № 1014-p of 16.10.2014 «On approval of the short- and middle-term measures plan for reducing natural gas consumption until 2017». (Ukr)

7. CMU Ordinance № 293 of 9.07 .2014 «On incentives for replacing natural gas in heat supply». (Ukr)

8. CMU Ordinance № 453 of 10.09.2014 «On incentives for replacing natural gas for heat production for budget-financed institutions»». (Ukr)

9. CMU Ordinance № 491 of 1.10 .2014 «On amending the Order for the use of budgetary funds intended for energy efficiency and energy conservation measures». (Ukr)

10. CMU Ordinance № 791-p of 3.09.2014 «On approval of the plan for implementing Directive 2009/28/EC of the European Parliament and of the Council». (Ukr) 